Article

\title{
How Do Modern Extreme Hydrothermal Environments Inform the Identification of Martian Habitability? The Case of the El Tatio Geyser Field
}

\section{Roberto Barbieri * and Barbara Cavalazzi}

Dipartimento di Scienze Biologiche, Geologiche e Ambientali, Università di Bologna, Via Zamboni 67, 40126 Bologna, Italy; E-Mail: barbara.cavalazzi@unibo.it

* Author to whom correspondence should be addressed; E-Mail: roberto.barbieri@ unibo.it; Tel.: +39-051-209-4575; Fax: +39-051-209-4522.

External Editors: Vera Kolb and Jesus Martinez-Frias

Received: 26 August 2014; in revised form: 27 October 2014 / Accepted: 3 November 2014 /

Published: 13 November 2014

\begin{abstract}
Despite the success in knowledge gained by the Mars missions in the last two decades, the search for traces of life on Mars is still in progress. The reconstruction of (paleo-) environments on Mars have seen a dramatic increase, in particular with regard to the potentially habitable conditions, and it is now possible to recognize a significant role to subaerial hydrothermal processes. For this reason, and because the conditions of the primordial Earth — when these extreme environments had to be common — probably resembled Mars during its most suitable time to host life, research on terrestrial extreme hydrothermal habitats may assist in understanding how to recognize life on Mars. A number of geological and environmental reasons, and logistics opportunities, make the geothermal field of El Tatio, in the Chilean Andes an ideal location to study.
\end{abstract}

Keywords: El Tatio geyser field; microbial life; martian life traces detection; mars analog habitats

\section{Introduction}

Since the pioneering work by Brock at the Yellowstone National Park [1], the identification of hyperthermophilic microorganisms has opened an extraordinary field for the study of the early evolution 
of life on Earth. With different metabolic strategies, prokaryotes preferring high temperature environments appear to be among the Earth's most plausible primitive organisms [2-5]. The reason for their importance lies in the characteristics of the habitats occupied by modern thermophiles and hyperthermophiles: a unique set of conditions that characterized the early Earth and interconnected energy (geothermal), chemical processes, and aqueous fluid transport through the Earth's crust [6,7] at the dawn of biological evolution. The extreme antiquity of the hyperthermophiles (e.g., [5,8,9]) justifies the debate on their position relative to the origin of life (e.g., [10-12]).

Despite being present on all of the continents with the exception of Antarctica [13], if the hydrothermal environments are today a relatively rare phenomenon, they were common in the primordial Earth. Hydrothermalism depends on volcanic activities on land, in the seafloor, and in the deep subsurface, and provides habitats for chemosynthetic, (hyper-)thermophilic microbial life forms in the deep (sea or land) systems, while at the surface they are active competitors of photosynthetic ones. Whereas in the seafloor the geothermal areas are usually close to an oceanic ridge, on land they are associated with different types of volcanic emissions. In both cases, the resulting hydrothermal systems depend on the heating and the emission of water at high temperatures. Because this combination of liquid water and energy sources is considered necessary for life also outside of the Earth, hydrothermal environments detected on Mars are among the most promising targets for searching for traces of possible extraterrestrial life. Achieving this goal, however, requires in-depth knowledge about the types of biosignatures that may be present in extreme hydrothermal habitats and their mode of fossilization, preservation, and detection in the only place that is subject to our direct observation: the Earth. This paper focuses, therefore, on the significance of the extreme hydrothermal systems in continental settings and their relevance in an astrobiological perspective and habitability estimate.

Hydrothermal phenomena that occur in continental (subaerial) areas represent an obvious facilitation for both physical and biological observations of these types of environments. Moreover, because the hydrothermal systems sustain a wide variety of biospaces for a number of microorganisms throughout the geological history of the Earth (since at least the early Archean), their significance in terms of Martian habitability, as models of possible life on that planet through time, is potentially enormous.

Without the buffering effect of the seawater and conditioned by a different water chemistry from site to site, subaerial hydrothermalism produces more demanding environmental conditions compared to those of the deep-sea. In terms of acidity, for example, the scenario for subaerial sites is extremely diverse. At Yellowstone National Park, for example, most of the geyser basins are alkaline, and only a few have acidic waters [14], whereas other important geothermal areas, such as El Tatio in the Chilean Andes, have nearly neutral pH [15]. Differently, other sites display extremely acidic conditions, as in the case of the Dallol Volcano (Danakil Depression) where $\mathrm{pH}$ values much lower than 1 were measured from escaping gas [16] and waters [17]. Large variations in the levels of temperature and acidity determine the colonization by different extremophiles, with communities of meso-, thermo-, hyperthermophiles, and acidophilic thermophiles that are responsible for striking differences in color as a product of their pigments. These differences are largely used for defining field zonation of the microbial communities (biofacies) (Figure 1). 
Figure 1. El Tatio Geyser Field (Chilean Andes): overview of the middle geyser basin. The different color on the surface depends on the distribution of the different microbial communities that are a consequence of the gradients of water temperature. The white color in the background comes from surface precipitation of salts.

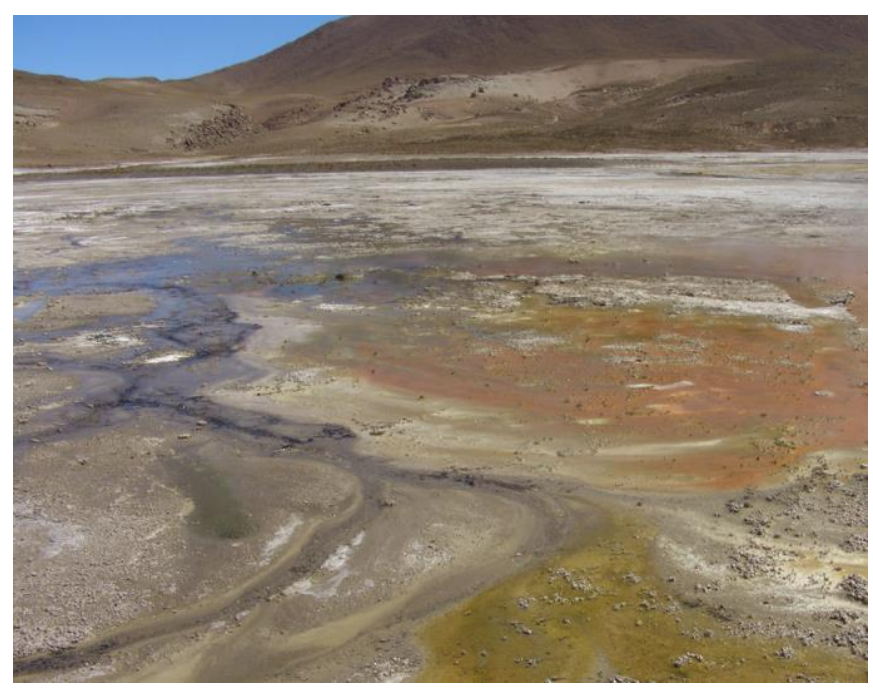

The Earth is not the only known place in the solar system where hydrothermalism and associated phenomena, such as geysers or geyser-like eruptions, are described or suggested. The Saturnian moon Enceladus is the most recent body of the solar system for which geysers - or jet-like eruptions produced by water vapor, ice grains, and other compounds that can be roughly compared with geysers-were proposed [18,19]. On Triton, the largest moon of Neptune, geyser-like vents seem to be produced by nitrogen gas [20], whereas on Dione and Tethys, two other Saturnian moons, ice geysers might be present [21]. In addition, on Jupiter's moon Europa hydrothermal vents are assumed [22].

Taking into consideration Mars, a number of observed features are associated with jet-like eruptions (e.g., [23]) and real hydrothermal activity — in particular impact-induced hydrothermalism and ventingincluding surface morphologies, mineral compositions, and stratigraphic evidences likely related to the earliest stages of its geological history (e.g., [24-26]). Despite the still limited knowledge of the paleoenvironmental context in which the hydrothermal deposits of Mars accumulated, many of them are presumed to have been formed in subaerial emerged or continental aquatic environments, such as lakes (e.g., [27]), that would have been produced inside impact craters. Also in Gusev crater, where there has been described the best example of hydrothermalism on Mars ([28-30]), is suggested the formation of an ephemeral lake [31] with evidences consistent with evaporite precipitation. The interest for this impact crater is also due to near-neutral $\mathrm{pH}$ conditions - a favorable factor for life - suggested by the detection of carbonates of a presumably hydrothermal origin [30,32]. Even products of what is interpreted as derived from geyser activity seem of subaerial environment. Similar to their terrestrial analogues, an important aspect of these Martian subaerial hydrothermal deposits, which could contribute to the reconstruction of the planet's evolution over time, is that they could convey information on hydrothermal fluid flow circulation of the deep subsurface (that cannot yet be achieved) up to the planet's surface. 


\section{Hydrothermalism: Early Earth and Present-Day}

Modern hydrothermal environments are among those that can best represent the conditions under which life may have been set during the very early Archean Eon. The reasons why life may have started in this type of environment are manifold. Hydrothermal environments were widespread during the primordial Earth in both submarine and subaerial areas. Although the problem of the thermal regime of the Earth's surface at around $4 \mathrm{Ga}$ ago is still debated (e.g., [7,33,34]), at that time the temperatures are assumed to have been much higher than today. The ocean temperatures have been estimated (from $\delta^{18} \mathrm{O}$ values measured on unaltered Archean cherts) between 50 and 70 degrees centigrade [35,36], and extreme, high temperature environments were documented by hydrothermal fluid alterations in early Archean rocks [37]. Moreover, the earliest known life belongs to hyperthermophilic Archaea [38], as also indicated by molecular data [4]. Further evidence of possibly favorable living conditions for hyperthermophiles comes from the proposed model of the thermal state during the late Hadean-early Archean Eons characterized by the intense late heavy bombardment, LHB (ended approx. 3.9-3.8 Ga ago) $[39,40]$. The results of this modeling suggest that the effects of the LHB appear insufficient to eradicate microbial life, and this may have interesting implications for understanding the real chances of habitability offered by a heavily cratered planet surface as was Mars during the Noachian.

Since their discovery in the late 1970s [41], the knowledge on the biological-related processes of the seafloor hydrothermal systems has rapidly progressed. One of the most outstanding systems discovered to date is Lost City, a hydrothermal field located near the mid-Atlantic Ridge [42]. The importance of this site stems from its peridotite-seawater alteration system - a type of rock/water interaction that is considered as a possible equivalent of Hadean hydrothermal environments [43,44] — and, also, on the dual (abiotic and biotic) origin of the methane carried by its vent fluids [45]. In deep submarine hydrothermal systems hyperthermophiles are typified by a chemolithoautotrophic mode of nutrition that makes them ideal candidates for colonizing a primitive Earth, with extremely active volcanism, intense meteorite impacts, and overall reducing (oxygen deficiency) conditions [7,46]. In the event that life first appeared through chemolithoautotrophy [47], ecosystems such as Lost City may, therefore, have a primary role for understanding how it arose.

Together with hydrothermal vents in the deep ocean, thermophiles and hyperthermophiles inhabit subaerial biotopes close to active volcanoes or near surface waters heated by intrusions of magmatic bodies. In these environments thermophiles are not limited to chemolithoautotrophy, as are the archaea of the deep oceans. They also include cyanobacteria and anaerobic photosynthetic bacteria. Some of these phototrophs commonly produce mats in geothermal water temperatures that may even exceed $80{ }^{\circ} \mathrm{C}$ [48].

As far as cyanobacteria are concerned, their relevance in terms of the possibility of being found in the fossil record is mainly dependent on their combined ability of withstanding harsh environmental conditions (e.g., [49]) and their high fossilization potential (e.g., [50,51]). A typical case is that of the desiccation-tolerant and radiation-resistant coccoid Chroococcidiopsis, one of the most primitive cyanobacteria, which is able to live in a wide range of extremely severe conditions (e.g., [52-54]), including hot springs, and was also proposed as a pioneer microorganism for terraforming Mars [55]. Although it is probably the most striking example, Chroococcidiopsis is not the only case of strongly extremophile cyanobacterium. Limited to the case of thermophiles, cyanobacteria are found in many 
high temperature springs, where filamentous genera produce multi-layered sheets and streamer morphologies. Organics produced by cyanobacterial mats can also allow the existence of thermophilic organotrophs, such as the genera Calditerrivibrio, Desulfurella, and Thermus, such as in Kamchatka [56] and other hot spring regions.

\section{Hydrothermalism: Martian Environments}

Volcanic-related deposits of presumably hydrothermal origin have been detected in a number of Martian regions (see review by [26]), which is consistent with the planet's geology characterized by the ubiquitous presence of basaltic volcanism. In this respect, the Noachian-aged Gusev crater, the landing site of the MER (Mars Exploration Rovers) Spirit, has a particular significance. At this site, the sensational discovery of opaline silica deposits has been interpreted as the product of hydrothermal conditions [29] because of its association with volcanic materials. More recent work [30] has supported the interpretation that opal-A outcrops were the product of a hot spring or geyser environment with a depicted scenario in which volcanic-related hydrothermal fluids allowed the precipitation of silica sinter deposits. Evidence of subaerial-interpreted hydrothermal environments was also described in the Hesperian-aged silica deposits on the flank of a volcanic cone in a caldera of Syrtis Major [57]. Because certain terrestrial hydrothermal systems share several primary environmental conditions with Mars, they may conveniently be considered as its environmental analogues. This is the case, for example, of highaltitude and/or glaciovolcanic hydrothermal environments [58], because the intense radiation and the permanent frost that characterizes them are ubiquitous environmental factors on Mars.

Mineral compositions and morphologies that are interpreted as being of hydrothermal origin — such as hydrated minerals (suggesting water-rock interactions), volcanic activity, and small dome morphologies (suggesting vent activity) - make the example that was described regarding the Majuro impact crater rather interesting [59]. Similar dome-shaped structures exist in other Martian impact crater areas $[60,61]$, that are interpreted as the product of hydrothermal circulation and have terrestrial analogs $[62,63]$.

Ancient (Noachian) crusts that were also detected in different areas [64,65] were related to aqueous alteration from volcanic-derived hydrothermalism. Another finding of great significance that implies hydrothermal alteration concerns carbonates and hydrated silicate minerals of a seemingly hydrothermal origin exhumed by an ancient meteor impact adjacent to Syrtis Major, a wide volcanic province [66]. This latter finding has relevance for Martian habitability because, similarly to the Earth in both subaerial and seafloor environments, it combines hydrothermalism and a carbonate record, thus establishing chemical environments that could be potentially suitable to host living communities.

Although no site on the Earth's surface can be strictly considered environmentally as an analog of Mars today, certain parameters that are useful for reconstructing the primordial conditions presumed for the red planet exist somewhere. A case of particular importance is that of the Atacama area, a wide, north-south oriented region encompassing parts of Peru, Bolivia and Chile, and including the plateau of the Atacama Desert and the Andean bordering regions. Because of the altitude and latitude of these sites, a number of environmental parameters similar to those of ancient Mars are present together and include a low average temperature, high-daily temperature variations, thin atmosphere, high solar irradiance, ice, reduced yearly precipitation, and a volcanic and hydrothermal environment. Because of this unique set 
of conditions, NASA-funded researchers undertook an extensive study in preparation for the search for life on Mars (e.g., [67,68]). In the Chilean Andes, near the Atacama Desert, is located the geothermal site of El Tatio, the largest geyser field in the southern hemisphere. Ringed by high volcanoes, El Tatio includes the environmental factors mentioned above to which are subjected the local microbiotic components. This biota, however, can leave a permanent record mainly through permineralization by the silica of a rich variety of morphologies and sub-environments [69-71] (Figures 2 and 3). The field has, therefore, a unique potential in the practical evaluation of the role of hydrothermal sites for the search for life on Mars.

Figure 2. El Tatio Geyser Field (Chilean Andes): alveolar network produced by mucilaginous sheaths of filamentous bacteria along the edge of an output channel from a pool of hot water. In (A) the network is fresh (coin diameter: $2.5 \mathrm{~cm}$ ), in $(\mathbf{B})$ it is permineralized by silica and delivered to the rock record (hammer for scale).
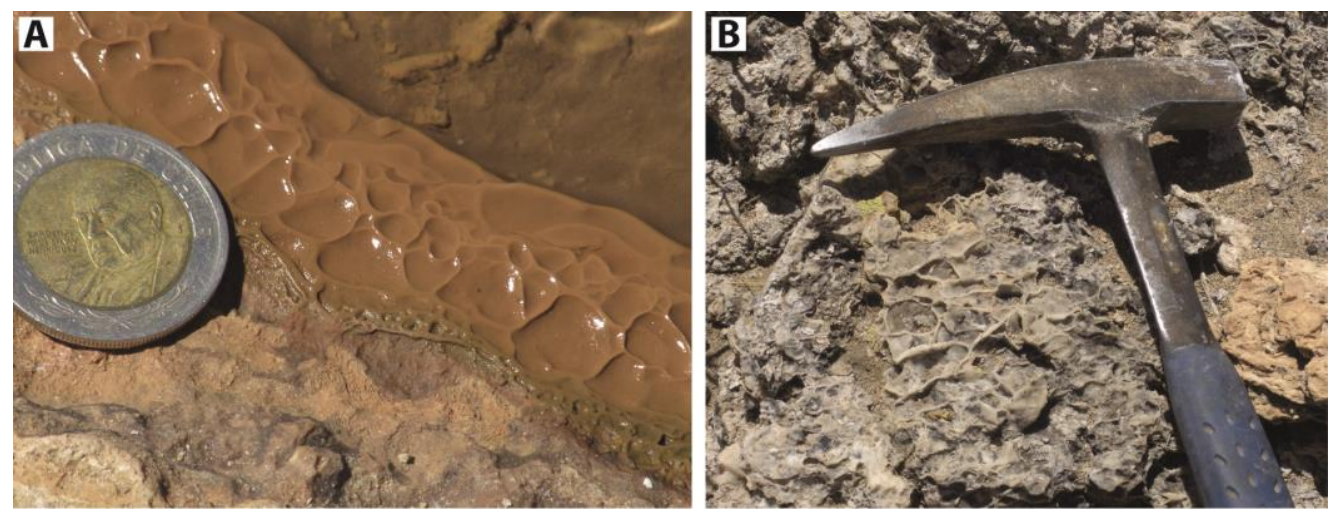

Figure 3. El Tatio Geyser Field (Chilean Andes). (A) Filamentous streamers from an outflow channel departing from a hot spring pool (flow direction: top to bottom) (hammer for scale); (B) SEM micrograph of a fresh streamer surface consisting of bundles of filamentous microbes (and diatom frustules) embedded in biofilms. Scale bar: $60 \mu \mathrm{m}$.
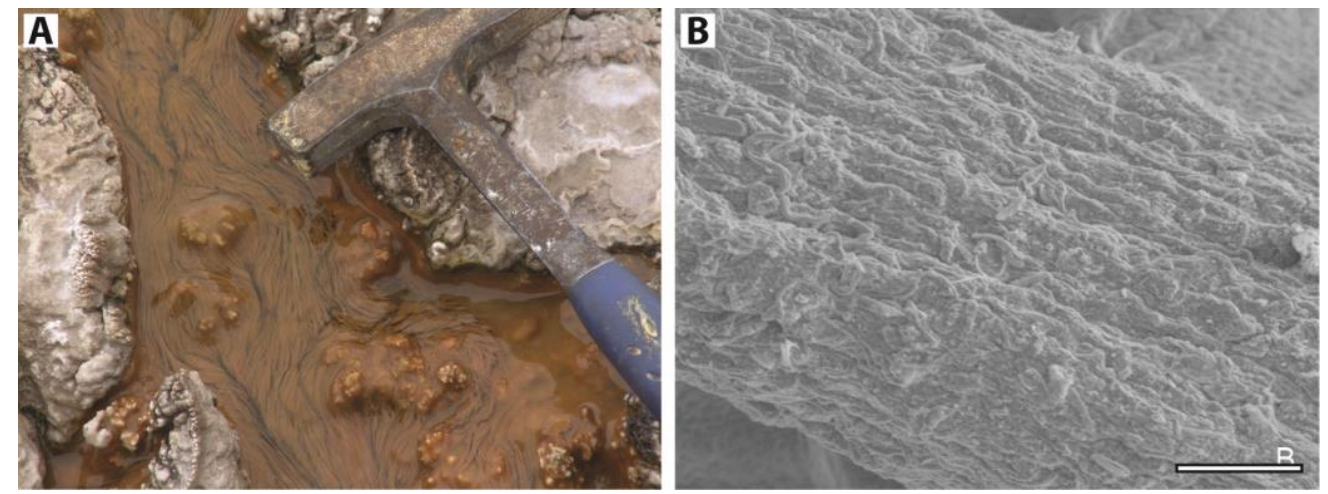

\section{Los Géiseres del Tatio}

Together with other high mountain geothermal fields, such as the Daggyai Tso in Tibet, El Tatio is the world's highest geyser field and it is the third largest field in the world, after the Yellowstone National Park (USA) and Dolina Geizerov (Russia). The area includes approx. $10 \mathrm{~km}^{2}$ in the Andean Altiplano of the Western Cordillera (Chilean Andes), at more than 4200 meters above sea level, 
with hundreds of erupting springs, fountain geysers erupting from boiling water pools, cone geysers, fumaroles, and mudpots set on a volcanic substrate [72]. Because of its unique setting, the diversity of geothermal environments, and other factors described below, El Tatio is a site of significant astrobiological relevance.

The main reason that makes the astrobiological relevance of El Tatio significant is its quality as environmental analog after the detection on the surface of Mars - by means of both rover missions and remote observations - of a combination of features (mineral/rock compositions, stratigraphic settings and morphologies) that can only be explained by subaerial hydrothermalism in a number of locations (e.g., Arabia Terra, Gusev Crater, Juventae Chasma, Valles Marineris, and others).

The astrobiological relevance of El Tatio deposits and the hydrothermal sites in general also depends on their potential to host life (habitable extreme environment [73]) and their ability to preserve the remnants of life (biosignatures) over geologic time (e.g., [74]). These favorable conditions are enhanced by the well-established assumption that the chances of finding evidence of extant or extinct Martian life are significantly higher in the subsurface than in the surface (e.g., [75]), and hydrothermal systems are excellent sites for life underground as well as on the surface. The assumption that if life forms are present in Martian hydrothermal systems they would most probably be fossilized depends on the general assumption that hydrothermal processes may have been extremely active in the Noachian and Hesperian periods $([26,60,76]$, the early phases of the geologic evolution of Mars. At that time, Mars presumably experienced greenhouse-like conditions with abundant liquid (nutrient-rich) water that was probably supported by an allegedly thicker atmosphere than today - therefore able to maintain water in the liquid state on the surface - and numerous geomorphologic and geochemical features [77-79]. Not only was the planet warmer and wetter, but also a lively volcanic activity contributed to shaping the entire geological provinces on Mars producing extensive basalt [80,81] and pyroclastic [82] deposits. A combination of the above-mentioned conditions - especially liquid water and heat able to provide nutrients and energy for life - makes the formation of hydrothermal environments and hydrothermally altered rocks likely. Similar to what has been observed on Earth, the persistence of habitable environments produced by hydrothermalism on Mars could also have favored the establishment of residual oases where life might have lasted even during the progressive drying and cooling of the planet [83].

The astrobiological relevance of El Tatio is also founded on its extensive volcanic province, which can be compared to analogous provinces described on Mars. The El Tatio region also includes abundant products of explosive volcanic eruptions, such as the ignimbrites, and similar friable surface deposits have also been detected on Mars and (at least in part) interpreted as pyroclasts (including ignimbrites) [82,84]. Because of their easy alterability the ignimbrites can easily record the effect of hydrothermal activity and this is well documented at El Tatio [69-71], where opaline deposits (geyserite) hold together the profoundly altered ignimbrite rock making up most of the substrate of the entire geothermal field. The three above-mentioned points make El Tatio a solid analog of Martian volcanic environments.

Another reason that makes El Tatio a site of special significance in hydrothermal environments is that hydrothermalism might still exist present-day on Mars. Evidence that makes plausible a persistence of endogenic- and/or exogenic-driven hydrothermal activities includes geomorphologic, geologic, and compositional aspects (see discussion in [26]). This possibility makes the modern living 
ecosystems on Earth, with environments as close as possible to the conditions present on Mars, a fertile subject of investigation to understand how and through which tools the signs of life can be detected. This is the case for high altitude hydrothermal areas, such as the Andean Altiplano of northern Chile (El Tatio, Puchuldiza) and Tibet (Yangbajing), combining a unique collection of extreme conditions that challenge the adaptability of many groups of extremophiles. At El Tatio waters, in addition, several unusually high element concentrations - such as arsenic, possibly related to the leaching of metal sulfides of volcanic origin [15] - contribute to its definition as a unique, extreme hydrothermal environment. High silica concentrations also have a strong astrobiological relevance. The reason is twofold: first, the abundance of silica precipitate favors the preservation of the bio-induced features and, therefore, may allow the recovery of Martian fossils, if any; second, some silica encrustation seems to provide effective protection from ultraviolet radiation in hot spring environments $[85,86]$. This second aspect is remarkable because protective strategies from UV radiation on present-day Mars should be considered to provide a reasonable chance of habitability. Unlike the Earth, the Martian UV flux has presumably increased over time and, compared to early Mars, its present UV radiation seems to be a constraint to the evolution of life [87].

Lastly, the astrobiological relevance of El Tatio is founded on the speculation that on Earth most of the primitive organisms would have had a hyperthermophilic mode of life and this implies that the Archean terrestrial life might have started from hydrothermal environments $[4,88,89]$. This astrobiological relevance is based on the assumption that the understanding of early Archean life and the ways of how it formed could help in the search for signs of life on Mars [90]. Hydrothermal environments set above the volcanic substrates of high altitude, as in the case of El Tatio, can reasonably approximate the conditions of the primordial Earth, which, in turn, seems comparable to what has been assumed for the habitability of Mars during the Noachian and Hesperian Periods.

\section{Conclusions}

Hydrothermal deposits are documented from different Martian regions and for a number of them has been hypothesized a subaerial emerged or continental aquatic environment. Because on Earth these hydrothermal systems sustain a wide variety of biospaces for a number of microorganisms throughout its geological history, their relevance for the search of life evidence and habitable environments is potentially enormous. In this regard, the hydrothermal site of El Tatio displays an importance as environmental analog, which is determined by the relatively easy access to a unique combination of physical, geological, and environmental features - that can approximate the early Mars (and Earth) conditions - their interaction with biota, and delivery to the rock record.

\section{Acknowledgments}

We acknowledge financial support from FP7-PEOPLE-2013-CIG (Grant 618657 INACMa) and the University of Bologna. We also thank Steve Ruff and an anonymous reviewer for their careful comments. 


\section{Author Contributions}

The two authors had the original idea and carried out the fieldwork. Roberto Barbieri drafted the manuscript, which was revised by Barbara Cavalazzi. Both authors read and approved the final manuscript.

\section{Conflicts of Interest}

The authors declare no conflict of interest.

\section{References}

1. Brock, T.D. Life at high temperatures. Science 1967, 158, 1012-1019.

2. Brock, T.D. Thermophilic Microorganisms and Life at High Temperatures; Springer-Verlag: Berlin/Heidelberg, Germany; New York, NY, USA, 1978.

3. Stetter, K.O.; Fiala, G.; Huber, G.; Huber, G.; Segerer, A. Hyperthermophilic microorganisms. FEMS Microbiol. Rev. 1990, 75, 117-124.

4. Stetter, K.O. Hyperthermophiles in the history of life. In Evolution of Hydrothermal Ecosystems on Earth (and Mars?); Bock, G.R., Goode, J.A., Eds.; Wiley: Chichester, UK, 1996; pp. 1-18.

5. Stetter, K.O. Hyperthermophiles in the history of life. Phil. Trans. R. Soc. 2006, B361, 1837-1843.

6. Lowell, R.P. Modeling continental and submarine hydrothermal systems. Rev. Geophys. 1991, 29, 457-476.

7. Arndt, N.T.; Nisbet, E.G. Processes on the young Earth and the habitats of early life. Annu. Rev. Earth Planet. Sci. 2012, 40, 521-549.

8. Delaye, L.; Becerra, A.; Lazcano, A. The nature of the last common ancestor. In The Genetic Code and the Origin of Life; de Pouplana, L.R., Ed.; Kluwer Academic: New York, NY, USA; Plenum Publishers: New York, NY, USA, 2004; pp. 34-47.

9. Stetter, K.O. Volcanoes, hydrothermal venting, and the origin of life. In Volcanoes and the Environment; Martì, J., Ernst, G.G.J., Eds.; Cambridge University Press: Cambridge, UK, 2005; pp. 175-206.

10. Pace, N.R. Origin of life-Facing up to the physical setting. Cell 1991, 65, 531-533.

11. Miller, S.L.; Lazcano, A. The origin of life-Did it occur at high temperatures? J. Mol. Evol. 1995, 41, 689-692.

12. Gribaldo, S.; Forterre, P. Looking for the most "primitive" life forms: Pitfalls and progresses. In Lectures in Astrobiology; Gargaud, M., Barbier, B., Martin, H., Reisse, J., Eds.; Springer: Berlin, Germany, 2006; Volume 1, pp. 195-215.

13. Waring, G.A. Thermal Springs of the United States and Other Countries of the World, A Summary. US Geological Survey: Reston, VA, USA, 1965.

14. Rowe, J.J.; Fournier, R.O.; Morey, G.W. Chemical analysis of thermal waters in Yellowstone National Park, Wyoming, 1960-1965. Geol. Surv. Bull. 1973, 1303, 1-31.

15. Cortecci, G.; Boschetti, T.; Mussi, M.; Herrera Lameli, C.; Mucchino, C.; Barbieri, M. New chemical and original isotopic data on waters from El Tatio geothermal field, northern Chile. Geochem. J. 2005, 39, 547-571. 
16. Darrah, T.H.; Tedesco, D.; Tassi, F.; Vaselli, O.; Cuoco, E.; Poreda, R.J. Gas chemistry of the Dallol region of the Danakil Depression in the Afar region of the northern-most East African Rift. Chem. Geol. 2012, 339, 16-29.

17. Cavalazzi, B.; Barbieri, R.; Hagos, M.; Capaccioni, B.; Agangi, A.; Gasparotto, G.; Palazzo, Q.; Kiros, K.; Glamoclija, M.; Rossi, A.P. Extreme among Extremes: Salt and Sulphur Springs of the Dallol (Danakil Depression, Ethiopia) and Their Astrobiological Role. In Proceedings of the 14th European Astrobiology Conference (EANA 2014), Edinburgh, UK, 13-16 October 2014.

18. Porco, C.C.; Helfenstein, P.; Thomas, P.C.; Ingersoll, A.P.; Wisdom, J.; West, R.; Neukum, G.; Denk, T.; Wagner, R.; Roatsch, T.; et al. Cassini observes the active south pole of Enceladus. Science 2006, 311, 1393-1401.

19. Iess, L.; Stevenson, D.J.; Parisi, M.; Hemingway, D.; Jacobson, R.A.; Lunine, J.I.; Nimmo, F.; Armstrong, J.W.; Asmar, S.W.; Ducci, M.; et al. The gravity field and interior structure of Enceladus. Science 2014, 344, 78-80.

20. Soderblom, L.A.; Kieffer, S.W.; Becker, T.L.; Brown, R.H.; Cook, A.F.; Hansen, C.J.; Johnson, T.V.; Kirk, R.L.; Shoemaker, E.M. Triton's geyser-like plumes: Discovery and basic characterization. Science 1990, 250, 410-415.

21. Burch, J.L.; Goldstein, J.; Lewis, W.S.; Young, D.T.; Coates, A.J.; Dougherty, M.K.; André, N. Tethys and Dione as sources of outward-flowing plasma in Saturn's magnetosphere. Nature 2007, $447,833-835$.

22. Lipps, J.H.; Rieeboldt, S. Habitats and taphonomy of Europa. Icarus 2005, 177, 515-527.

23. Kieffer, H.H.; Christensen, P.R.; Titus, T.N. $\mathrm{CO}_{2}$ jets formed by sublimation beneath translucent slab ice in Mars' seasonal south polar ice cap. Nature 2006, 442, 793-796.

24. Farmer, J.D. Hydrothermal systems on Mars: An assessment of present evidence. In Evolution of Hydrothermal Ecosystems on Earth (and Mars?); Bock, G.R., Goode, J.A., Eds.; Wiley: Chichester, UK, 1996; pp. 273-295.

25. Pirajno, F.; van Kranendonk, M.J. Review of hydrothermal processes and systems on Earth and implications for Martian analogues. Aust. J. Earth Sci. 2005, 52, 329-351.

26. Schulze-Makuch, D.; Dohm, J.M.; Fan, C.; Fairén, A.G.; Rodriguez, J.A.P.; Baker, V.R.; Fink, W. Exploration of hydrothermal targets on Mars. Icarus 2007, 189, 308-324.

27. Newsom, H.E. Heated lakes on Mars. In Lakes on Mars; Cabrol, N.A., Grin, E.A., Eds.; Elsevier: Amsterdam, The Netherlands, 2010; pp. 93-110.

28. Squyres, S.W.; Aharonson, O.; Clark, B.C.; Cohen, B.A.; Crumpler, L.; de Souza, P.A.; Farrand, W.H.; Gellert, R.; Grant, J.; Grotzinger, J.P.; et al. Pyroclastic activity at Home Plate in Gusev crater, Mars. Science 2007, 316, 738-742.

29. Squyres, S.W.; Arvidson, R.E.; Ruff, S.W.; Gellert, G.; Morris, R.V.; Ming, D.W.; Crumpler, L.; Farmer, J.D.; des Marais, D.J.; Yen, A.; et al. Detection of silica-rich deposits on Mars. Science 2008, 320, 1063-1067.

30. Ruff, S.W.; Farmer, J.D.; Calvin, W.M.; Herkenhoff, K.E.; Johnson, J.R.; Morris, R.V.; Rice, M.S.; Arvidson, R.E.; Bell, J.F., III; Christensen, P.R.; et al. Characteristics, distribution, origin, and significance of opaline silica observed by the Spirit rover in Gusev crater, Mars. J. Geophys. Res. 2011, 116, doi:10.1029/2010JE003767. 
31. Ruff, S.W.; Niles, P.B.; Alfano, F.; Clarke, A.B. Evidence for a Noachian-aged ephemeral lake in Gusev crater, Mars. Geology 2014, 42, 359-362.

32. Morris, R.V.; Ruff, S.W.; Gellert, R.; Ming, D.W.; Arvidson, R.E.; Clark, B.C.; Golden, D.C.; Siebach, K.; Klingelhöfer, G.; Schröder, C.; et al. Identification of carbonate-rich outcrops on Mars by the Spirit rover. Science 2010, 329, 421-424.

33. Kasting, J.F.; Howard, M.T. Atmospheric composition and climate on the early Earth. Phil. Trans. R. Soc. 2006, B361, 1733-1742.

34. Lunine, J.I. Physical conditions on the early earth. Phil. Trans. R. Soc. 2006, B361, 1721-1731.

35. Knauth, L.P. Origin and diagenesis of cherts: An isotopic perspective. In Isotopic Signatures and Sedimentary Records; Clauer, N., Chandhuri, S., Eds.; Springer: Berlin, Germany, 1992; pp. 123-152.

36. Robert, F.; Chaudisson, M. A paleotemperature curve for the Precambrian oceans based on silicon isotopes in cherts. Nature 2006, 443, 969-972.

37. Sleep, N.H. The Hadean-Archean environment. Cold Spring Harb. Perspect. Biol. 2010, 2, doi:10.1101/cshperspect.a002527.

38. Pace, N.R. A molecular view of microbial diversity and the biosphere. Science 1997, 276, 734-740.

39. Gomes, R.; Levison, H.F.; Tsiganis, K.; Morbidelli, A. Origin of the cataclysmic Late Heavy Bombardment period of the terrestrial planets. Nature 2005, 435, 466-469.

40. Abramov, O.; Mojzsis, S.J. Microbial habitability of the Hadean Earth during the late heavy bombardment. Nature 2009, 459, 419-422.

41. Corliss, J.B.; Dyamond, J.; Gordon, L.I.; Edmond, J.M.; von Herzen, R.P.; Ballard, R.D.; Green, K.; Williams, D.; Bainbridge, A.; Crane, K.; et al. Submarine thermal springs on the Galápagos rift. Science 1979, 203, 1073-1083.

42. Kelley, D.S.; Karson, J.A.; Blackman, D.K.; Früh-Green, G.L.; Butterfield, D.A.; Lilley, M.D.; Olson, E.J.; Schrenk, M.O.; Roe, K.K.; Lebon, G.T.; et al. An off-axis hydrothermal vent field near the Mid-Atlantic Ridge at $308^{\circ}$ N. Nature 2001, 412, 145-149.

43. Kelley, D.S.; Karson, J.A.; Früh-Green, G.L.; Yoerger, D.R.; Shank, T.M.; Butterfield, D.A.; Hayes, J.M.; Schrenk, M.O.; Olson, E.J.; Proskurowski, G.; et al. A serpentinite-hosted ecosystem: The Lost City Hydrothermal Field. Science 2005, 307, 1428-1434.

44. Foustoukos, D.I.; Savov, I.P.; Janecky, D.R. Chemical and isotopic constraints on water/rock interactions at the Lost City hydrothermal field, $30^{\circ} \mathrm{N}$ Mid-Atlantic Ridge. Geochim. Cosmochim. Acta 2008, 72, 5457-5474.

45. Bradley, A.S.; Summons, R.E. Multiple origins of methane at the Lost City Hydrothermal Field. Earth Planet. Sci. Lett. 2010, 297, 34-41.

46. Van Kranendonk, M.J.; Webb, G.E.; Kamber, B.S. Geological and trace element evidence for a marine sedimentary environment of deposition and biogenicity of $3.45 \mathrm{Ga}$ stromatolitic carbonates in the Pilbara craton, ans support for a reducing Archaean ocean. Geobiology 2003, 1, 91-108.

47. Gaucher, E.A.; Kratzer, J.T.; Randall, R.N. Deep phylogenyhow a tree can help characterize early life on earth. Cold Spring Harb. Perspect. Biol. 2010, 2, doi:10.1101/cshperspect.a002238. 
48. Klatt, C.G.; Inskeep, W.P.; Herrgard, M.J.; Jay, Z.J.; Rusch, D.B.; Tringe, S.G.; Parenteau, M.N.; Ward, D.M.; Boomer, S.M.; Bryant, D.A.; et al. Community structure and function of high-temperature chlorophototrophic microbial mats inhabiting diverse geothermal environments. Front. Microbiol. 2013, 4, 1-23.

49. Whitton, B.A. Ecology of Cyanobacteria II. Their Diversity in Space and Time; Springer: Dordrecht, The Netherlands, 2012.

50. Knoll, A.H. Cyanobacteria and earth history. In The Cyanobacteria. Molecular Biology, Genomics and Evolution; Herrero, A., Flores, E., Eds.; Caister Academic Press: Norfolk, UK, 2008; pp. 1-19.

51. Schopf, J.W. The fossil record of cyanobacteria. In Ecology of Cyanobacteria II. Their Diversity in Space and Time; Whitton, B.A., Ed.; Springer: Dordrecht, The Netherlands, 2012; pp. 15-36.

52. Billi, D.; Friedman, I.; Ocampo-Friedman, R. Ionizing-radiation resistance in the desiccation-tolerant cyanobacterium Chroococcidiopsis. Appl. Environ. Microbiol. 2000, 66, 1489-1492.

53. Baqué, M.; Viaggiu, E.; Scalzi, G.; Billi, D. Endurance of the endolithic desert cyanobacterium Chroococcidiopsis under UVC radiation. Extremophiles 2012, 17, 161-169.

54. Stivaletta, N.; Barbieri, R.; Billi, D. Microbial colonization of the salt deposits in the driest place of the Atacama Desert (Chile). Orig. Life Evol. Biosph. 2012, 42, 187-200.

55. Friedmann, E.I.; Ocampo-Friedmann, R. A Primitive cyanobacterium as pioneer microorganism for terraforming Mars. Adv. Space Res. 1995, 15, 243-246.

56. Gumerov, V.; Mardanov, A.; Beletsky, A.; Bonch-Osmolovskaya, E.; Ravin, N. Molecular analysis of microbial diversity in the Zavarzin spring, Uzon Caldera, Kamchatka. Microbiology 2011, 80, 244-251.

57. Skok, J.R.; Mustard, J.F.; Ehlmann, B.L.; Milliken, R.E.; Murchie, S.L. Silica deposits in the Nili Patera caldera on the Syrtis Major volcanic complex on Mars. Nat. Geosci. 2010, 3, 838-841.

58. Cousins, C.R.; Crawford, I.A.; Carrivick, J.L.; Gunn, M.; Harris, J.; Kee, T.P.; Karlsson, M.; Carmody, L.; Cockell, C.; Herschy, B.; et al. Glaciovolcanic hydrothermal environments in Iceland and implications for their detection on Mars. J. Volcanol. Geoth. Res. 2013, 256, 61-77.

59. Mangold, N.; Carter, J.; Poulet, F.; Dehouck, E.; Ansan, V.; Loizeau, D. Late Hesperian aqueous alteration at Majuro crater, Mars. Planet. Space Sci. 2012, 72, 18-30.

60. Marzo, G.A.; Davila, A.F.; Tornabene, L.L.; Dohm, J.M.; Fairen, A.G.; Gross, C.; Kneissl, T.; Bishop, J.L.; Roush, T.L.; McKay, C.P. Evidence for Hesperian impact-induced hydrothermalism on Mars. Icarus 2010, 208, 667-683.

61. Pondrelli, M.; Rossi, A.P.; Ori, G.G.; Van Gasselt, S.; Praeg, D.; Ceramicola, S. Mud volcanoes in the geologic record of Mars: The case of Firsoff crater. Earth Planet. Sci. Lett. 2001, 304, 511-519.

62. Franchi, F.; Cavalazzi, B.; Pierre, C.; Barbieri, R. New evidences of hydrothermal fluids circulation at the Devonian Kess Kess mounds, Hamar Laghdad (eastern Anti-Atlas, Morocco). Geol. J. 2014, doi:10.1002/gj.2582.

63. Franchi, F.; Rossi, A.P.; Pondrelli, M.; Cavalazzi, B. Geometry, stratigraphy and evidences for fluid expulsion within Crommelin crater deposits, Arabia Terra, Mars. Planet. Space Sci. 2014, 92, 3448. 
64. Mangold, N.; Poulet, F.; Mustard, J.F.; Bibring, J.-P.; Gondet, B.; Langevin, Y.; Ansan, V.; Masson, P.; Fassett, C.; Head, J.W., III; et al. Mineralogy of the Nili Fossae region with OMEGA/Mars. Express data: 2. Aqueous alteration of the crust. J. Geophys. Res. 2007, 112, doi:10.1029/2006JE002835.

65. Mustard, J.F.; Ehlmann, B.L.; Murchie, S.L.; Poulet, F.; Mangold, N.; Head, J.W.; Bibring, J.-P.; Roach, L.H. Composition, morphology, and stratigraphy of Noachian crust around the Isidis Basin. J. Geophys. Res. 2009, 114, doi:10.1029/2009JE003349.

66. Michalski, J.R.; Niles, P.B. Deep crustal carbonate rocks exposed by meteor impact on Mars. Nat. Geosci. 2010, 3, 751-755.

67. Cabrol, N.A.; Wettergreen, D.; Warren-Rhodes, K.; Grin, E.A.; Moersch, J.; Diaz, G.C.; Cockell, C.S.; Coppin, P.; Demergasso, C.; Dohm, J.M.; et al. Life in the Atacama: Searching for life with rovers (science overview) J. Geophys. Res. 2007, 112, doi:10.1029/2006JG000298.

68. Warren-Rhodes, K.; Weinstein, S.; Dohm, J.; Piatek, J.; Minkley, E.; Hock, A.; Cockell, C.; Pane, D.; Ernst, L.A.; Fisher, G.; et al. Searching for microbial life remotely: Satellite-to-rover habitat mapping in the Atacama Desert, Chile. J. Geophys. Res. 2007, 112, doi:10.1029/2006JG000283.

69. Jones, B.; Renaut, R.W. Formation of silica oncoids around geysers and hot springs at El Tatio, northern Chile. Sedimentology 1997, 44, 287-304.

70. Fernandez-Turiel, J.L.; García-Vallés, M.; Gimeno, D.; Saavedra-Alonso, J.; Martínez-Manent, S. The hot spring and geyser sinters of El Tatio, Northern Chile. Sedim. Geol. 2005, 180, 125-147.

71. Barbieri, R.; Cavalazzi, B.; Stivaletta, N.; Lopez-Garcia, P. Silicified biota in high-altitude, geothermally influenced ignimbrites at El Tatio Geyser Field, Andean Cordillera (Chile). Geomicrobiol. J. 2014, 31, 493-508.

72. Glennon, J.A.; Pfaff, R.M. The extraordinary thermal activity of El Tatio geyser field, Antofagasta Region, Chile. GOSA Trans. 2003, 8, 31-78.

73. Dohm, J.M.; Miyamoto, H.; Ori, G.G.; Fairén, A.G.; Davila, A.F.; Komatsu, G.; Mahaney, W.C.; Williams, J.-P.; Joye, S.B.; di Achille, G.; et al. An inventory of potentially habitable environments on Mars: Geological and biological perspectives. Geol. Soc. Am. Special Pap. 2011, 483, 317-347.

74. Cady, S.L.; Farmer, J.D. Fossilization processes in siliceous thermal springs: Trends in preservation along thermal gradients. In Evolution of Hydrothermal Ecosystems on Earth (and Mars?); Brock, G.R., Goode, J.A., Eds.; Wiley: Chichester, UK, 1996; pp. 150-173.

75. Michalski, J.R.; Cuadros, J.; Niles, P.B.; Parnell, J.; Rogers, A.D.; Wright, S.P. Groundwater activity on Mars and implications for a deep biosphere. Nat. Geosci. 2013, doi:10.1038/ngeo1706.

76. Pirajno, F. Hydrothermal Processes and Mineral-Systems; Springer: Berlin, Germany, 2010.

77. Baker, V.R. Water and the Martian landscape. Nature 2001, 412, 228-236.

78. Jakosky, B.M.; Phillips, R.J. Mars' volatile and climate history. Nature 2001, 412, 237-244.

79. Manga, M.; Patel, A.; Dufek, J.; Kite, E.S. Wet surface and dense atmosphere on early Mars suggested by the bomb sag at Home Plate, Mars. Geophys. Res. Lett. 2012, 39, doi:10.1029/2011GL050192.

80. Greeley, R.; Schneid, B.D. Magma generation on Mars: Amounts, rates, and comparisons with Earth, Moon, and Venus. Science 1991, 254, 996-998. 
81. Keszthelyi, L.; Mcewen, A. Comparison of flood lavas on Earth and Mars. In The Geology of Mars: Evidence from Earth-Based Analogs; Chapman, M.G., Ed.; Cambridge University Press: Cambridge, UK, 2007; pp. 126-150.

82. Kerber, L.; Head, J.W.; Madeleine, J.-B.; Forget, F.; Wilson, L. The dispersal of pyroclasts from ancient explosive volcanoes on Mars: Implications for the friable layered deposits. Icarus 2012, $219,358-381$.

83. Grasby, S.E.; Londry, K.L. Biogeochemistry of hypersaline springs supporting a mid-continent marine ecosystem: An analogue for martian springs? Astrobiology 2007, 7, 662-683.

84. Tanaka, K.L. Dust and ice deposition in the martian geologic record. Icarus 2000, 144, 254-266.

85. Phoenix, V.R.; Bennett, P.C.; Engel, A.S.; Tyler, S.W.; Ferris, F.G. Chilean high-altitude hot-spring sinters: A model system for UV screening mechanisms by early Precambrian cyanobacteria. Geobiology 2006, 4, 15-28.

86. Phoenix, V.R.; Konhauser, K.O. Benefits of bacterial biomineralization. Geobiology 2008, 6, 303308.

87. Cockell, C.S.; Catling, D.C.; Davis, W.L.; Snook, K.; Kepner, R.L.; Lee, P.; McKay, C.P. The ultraviolet environment of Mars: Biological implications past, present, and future. Icarus 2000, 146, 343-359.

88. Blank, C.E. Evolutionary timing of the origins of mesophilic sulphate reduction and oxygenic photosynthesis: A phylogenetic dating approach. Geobiology 2004, 2, 1-20.

89. Barion, S.; Franchi, M.; Gallori, E.; di Giulio, M. The first lines of divergence in the Bacteria domain were the hyperthermophilic organisms, the Thermotogales and the Aquificales, and not the mesophilic Planctomycetales. Biosystems 2007, 87, 13-19.

90. Evolution of Hydrothermal Ecosystems on Earth (and Mars?); Bock, G.R., Goode, J.A., Eds.; Wiley: Chichester, UK, 1996.

(C) 2014 by the authors; licensee MDPI, Basel, Switzerland. This article is an open access article distributed under the terms and conditions of the Creative Commons Attribution license (http://creativecommons.org/licenses/by/4.0/). 